\title{
ANALISIS KESALAHAN MAHASISWA BARU DALAM MENGERJAKAN SOAL-SOAL KALKULUS INTEGRAL TAK TENTU
}

\author{
Kairuddin \\ Dosen Pendidikan Matematik FMIPA Universitas Negeri Medan \\ Email : kairuddin2@yahoo.com
}

\begin{abstract}
ABSTRAK
Penelitian ini bertujan untuk mengetahui kesalahan mahasiswa baru dalam mengerjakan soalsoal kalkulus integral tak tentu. Dalam melakukan penelitian ini 5 (lima) mahasiswa baru dipilih sebagai responden. Mahasiswa tersebut sudah mempelajari mata kuliah kalkulus integral dan diberikan 5 (lima) butir soal dengan tingkat kesulitan soal mudah dan sedang. Dari hasil yang didapat bahwa seorang mahasiswa mampu mengerjakan dan memperoleh hasil yang benar 4 buah dari lima soal yang diberikan. Satu mahasiswa memperoleh tiga jawaban yang benar dari lima soal yang diberikan. Satu orang mahasiswa hanya mampu memperolah dua jawaban yang benar dari lima soal yang diberikan dan dua orang mahasiswa tidak mampu mendapatkan satu pun hasil akhir yang benar. Dari analisis jawaban respondan dan wawancara yang dilkukan ternyata mereka belum memahami konsep integral tak tentu dan prosedur pengerjaan soal.
\end{abstract}

Kata kunci: kalkulus integral, mahasiswa, soal

\begin{abstract}
This study aims to determine the errors of new students in working on indeterminate integral calculus questions. In conducting this study 5 (five) new students were selected as respondents. The student has studied integral calculus courses and given 5 (five) items with difficulty and easy problems. From the results obtained that a student is able to work on and obtain the correct results 4 pieces of the five questions given. One student gets three correct answers from the five questions given. One student is only able to get two correct answers from the five questions given and two students are not able to get even the correct final results. From the analysis of respondent's answers and interviews, it turned out that they did not understand the concept of indeterminate integrals and the procedure of working on the questions.
\end{abstract}

Keywords: integral calculus, students, questions

\section{Pendahuluan}

Undang-undang Nomor 20 Tahun 2003 tentang Sistem Pendidikan Nasional menyebutkan bahwa pendidikan formal yaitu jalur pendidikan yang terdiri dari jenjang pendidikan dasar, pendidikan menengah, dan pendidikan tinggi. Matematika termasuk salah satu pengetahuan yang perlu dipelajari pada semua jenjang pendidikan formal tersebut. Menurut Abdurrahman (2010), alasan perlunya mempelajari matematika sebab matematika merupakan (1) sarana berpikir yang jelas dan logis, (2) sarana untuk memecahkan masalah kehidupan seharihari, (3) sarana mengenal pola-pola hubungan dan generalisasi pengalaman, (4) sarana untuk mengembangkan kreativitas, dan (5) sarana untuk meningkatkan kesadaran terhadap perkembangan budaya. Karena perannya yang sangat penting, sehingga 
matematika dipelajari sampai dengan jenjang pendidikan tinggi.

Bidang matematika juga dipelajari mahasiswa di Program Studi Biologi Universitas Negeri Medan. Pada prodi tersebut, salah satu mata kuliah rumpun matematika bernama Kalkulus Integral, dengan bobot 3 sks. Pada kurikulum yang berlaku di Universitas Negeri Medan, mata kuliah ini ditempuh mahasiswa ketika mahasiswa berada pada semester dua. Dari silabus perkuliahan, kompetensi yang diharapkan tercapai dari mata kuliah ini adalah (1) mahasiswa mampu memahami konsep integral tertentu dan integral tak tentu serta penggunaannya untuk menghitung luasan dan volume benda putar, serta (2) mahasiwa mampu memahami konsep aljabar linear yang meliputi matriks, determinan dan invers matriks beserta penggunaannya pada penyelesaian sistem linear.

Dalam mempelajari mata kuliah kalkulus integral untuk melihat kemampuan mahasiswa dalam perkuliahan diberikan tes tertulis. Namun dalam mengerjakan soal sering mehasiswa tidak memahami maksud soal dan sering mengalami kesalahna dalam mengerjakan soal tentu saja karena mungkin ada kendala-kendalan dalam mengerjakan soal tersebut, maka dalam artikel ini penulis mencoba menemukan mengapa mahasiswa sering kurang memahami maksud soal, apa kesalahan yang dilakukan mahasiswa dalam mengerjakan soal dan apa yang menjadi kendala mahasiswa dalam mengerjakan soal.

\section{Tinjauan Pustaka}

Integral adalah kebalikan dari proses diferensiasi. Integral ditemukan menyusul ditemukannya masalah dalam diferensiasi dimana matematikawan harus berpikir bagaimana menyelesaikan masalah yang berkebalikan dengan solusi diferensiasi. Integral terbagi dua yaitu integral tak tentu dan integral tertentu. Bedanya adalah integral tertentu memiliki batas atas dan batas bawah. Integral tertentu biasanya dipakai untuk mencari volume, benda putar dan luas.

Penyelesaian soal integral membutuhkan pemahaman konsep yang baik, pemahaman rumus yang tepat, serta kejelian dan kreativitas yang tinggi. Proses yang kompleks ini menjadikan kesulitan tersendiri dalam mempelajari materi integral. Akibatnya, mahasiswa melakukan kesalahan dalam menyelesaikan soal-soal integral. Kesalahan-kesalahan ini perlu segera diidentifikasi melalui kegiatan analisis supaya tidak bedampak pada mata kuliah serumpun pada semestersemester berikutnya, seperti matematika diskrit dan metode numerik. Secara umum, jenis integral terdiri dari integral biasa, integral subtitusi dan integral parsial. Karena keterbatasan waktu dan tenaga dari peneliti, kesalahan mengerjakan soal integral dalam penelitian ini dibatasi pada jenis integral biasa dan integral subtitusi. Selain itu, alasan lainnya adalah kedua jenis integral tersebut digunakan sebagai pokok dasar materi integral. Diharapkan jika kesalahan pada pokok dasar materi teridentifikasi melalui kegiatan analisis kesalahan, maka kesalahan pada materi integral selanjutnya (integral parsial) dapat diminimalkan.

Analisis kesalahan menurut Rahmania \& Rahmawati (2016) adalah penyelidikan terhadap suatu bentuk penyimpangan atau kekeliruan dari jawaban tertulis siswa. Oleh karena itu, kesalahan mahasiswa mengerjakan soal integral dapat diidentifikasi dari kekeliruan yang bersumber dari lembar jawab mahasiswa. Lebih lanjut, jenis kesalahan dapat dikelompokkan

Kairuddin.. Analisis Kesalahan Mahasiswa Baru dalam Mengerjakan Soal-Soal Kalkulus Integral Tak Tentu. Jurnal Inspiratif, Vol 3. No. 3 Desember 2017 
menjadi kesalahan konsep, operasi dan prinsip (Manibuy, Mardiyana, \& Saputro, 2014; Rahmania \& Rahmawati, 2016).

Pengelompokan jenis kesalahan tersebut berkaitan dengan objek matematika. Mengadaptasi jenis kesalahan tersebut, dalam penelitian ini kesalahan yang dilakukan mahasiswa dalam menyelesaikan soal integral dikelompokkan dalam tiga jenis kesalahan, yaitu kesalahan konsep, kesalahan operasi dan kesalahan prinsip. Kesalahan mengerjakan soal integral dari segi konsep, operasi, dan prinsip yang dialami setiap mahasiswa dimungkinkan tidak sama. Ada mahasiswa yang mengalami kesalahan pada suatu bagian dan bagian lainnya benar, tetapi ada juga yang sebaliknya. Walaupun secara umum kesalahan tersebut dipengaruhi dari sisi intelegensi mahasiswa, tetapi keberagaman karakteristik mahasiswa juga turut mempengaruhi. Terdapat berbagai faktor karakteristik mahasiswa yang berpengaruh terhadap hasil belajar mahasiswa.

Menurut Slameto (Hikmawati, Kamid, \& Syamsurizal, 2013), salah satu faktor yang mempengaruhi hasil belajar matematika adalah faktor kognitif, yang meliputi aspek (1) persepsi (perseption), (2) perhatian (attention), (3) mendengarkan (listening), (4) ingatan (memory), (5) kesiapan (readiness), (6) struktur kognitif (cognitive structure), (7) inteligensi (intelligence), (8) kreativitas (creativity), dan (9) gaya kognitif (cognitive style).

Kesalahan mahasiswa dalam menyelesaikan soal kalkulus integral berdasarkan kognitif pembelajaran yang optimal terutama sekali dalam pembelajaran matematika (Hikmawati, Kamid, \& Syamsurizal, 2013). Selain itu, memperhatikan kognitif mahasiswa akan memberikan hasil yang optimal terhadap pemahaman mahasiswa ketika proses pembelajaran (Nurafni, 2016). Oleh sebab itu, aspek kognitif sangat penting diketahui pengajar agar dapat memahami bahwa mahasiswa yang hadir dalam pembelajaran memiliki cara yang berbedabeda dalam menghadapi masalah atau tugas-tugas yang diberikan (Athira, Bennu, \& Rizal, 2015). Melihat urgensi perlunya memahami aspek kognitif mahasiswa dalam meningkatkan kebermaknaan pembelajaran, meningkatkan pemahaman mahasiswa, serta memahami keberagaman mahasiswa dalam menghadapi tugas atau mengerjakan soal, maka peneliti tertarik untuk memfokuskan kognitif sebagai sudut peninjauan dalam melakukan analisis kesalahan.

\section{Metode Penelitian}

\section{Waktu dan Tempat Penelitian}

Penelitian dilakukan dengan memvalidasikan soal dilakukan di Ruang Diskusi Digital Library UNIMED dan di Prodi Biologi.

\section{Jenis Penelitian}

Pengambilan sampel dilakukan dengan memberikan beberapa soal kepada mahasiswa/i ada di Ruang Diskusi Digital Library UNIMED dan kemudian melakukan wawancara tentang bagaimana pandangannya terhadap soal dan materi tentang integral tak tentu. Pengambilan sampel yang dilakukan di ruang diskusi digital library UNIMED dengan jumlah sampel yang diambil sebanyak 5 orang dengan jumlah soal sebanyak 5 soal mengenai materi integral tak tentu.

\section{Rancangan Penelitian}

- Mempersiapkan materi yang akan dibuat jadi bahan test dan wawancara

Kairuddin.. Analisis Kesalahan Mahasiswa Baru dalam Mengerjakan Soal-Soal Kalkulus Integral Tak Tentu. Jurnal Inspiratif, Vol 3. No. 3 Desember 2017 
- Mempersiapkan soal test/kuis yang akan diberikan kepada mahasiswa/i sebagai bahan sampel

- Mempersiapkan rangkaian pertayaan tentang pendapat mahasiswa mengenai rangkaian soal test/kuis dan materi tentang integral tak tentu

\section{Instrumen Penelitian dan Teknik Pengumpulan Data}

Dalam memperoleh data saya menyiapkan serangkain soal test/kuis yang diberikan kepada mahasiswa/i dan melakukan wawancara tentang bagaimana pendapat mahasiswa tentang serangkain soal dan materi integral tak tentu

- Test/Kuis diberikan kepada mahasiswa dengan mengambil beberapa sampel sebagai bahan perbandingan data dengan jumlah soal 5 buah

- Wawancara, setelah mahasiswa menyelesaikan serangkain soal test/kuis melakukan proses wawancara untuk mengetahui

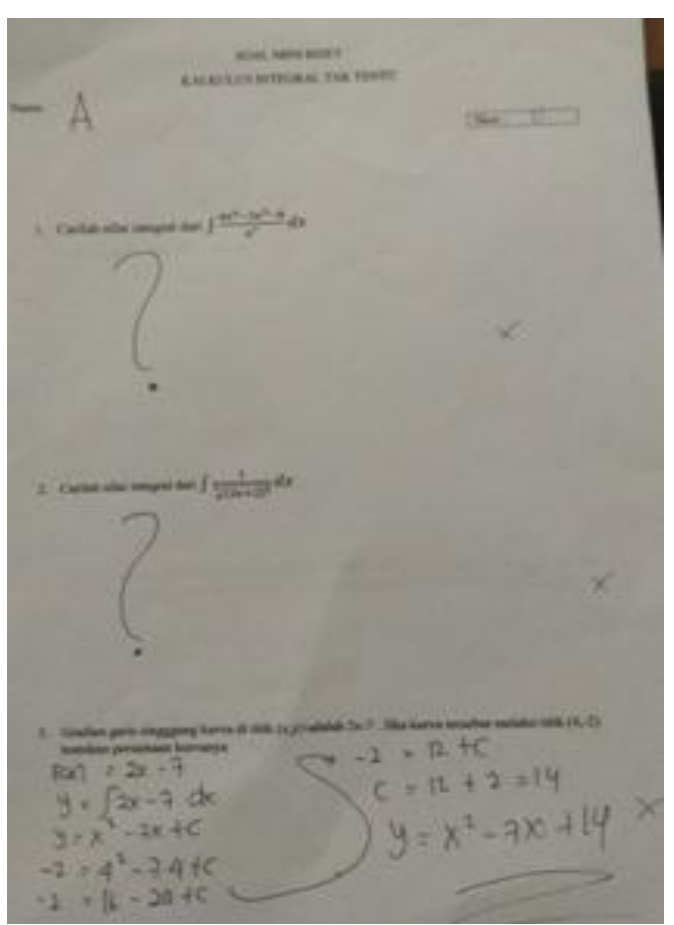

Gambar 1. Jawaban mahasiswa A bagaimana pendapat mahasiswa tentang serangkain soal test/kuis dan materi tentang integral tak tentu.

\section{Analisis Data}

Data yang sudah didapat dengan menggunakan beberapa sampel yaitu dengan memberikan serangkaian soal test /kuis dan proses wawancara. Hasil tes yang didapat kemudian di periksa apakah jawaban tersebut benar atau salah. Selanjutnya dilakukan wawancara dengan mahasiswa yang bersangkutan apa yang menjadi kendala mereka dalam mengerjkan soal. Jawaban mahasiswa dianalisis sehingga ditemukan hal apa saja yang menjadi titik kesalahan mahasiswa dalam mengerjakan soal dan kendala apa saja yang sering muncul ketika berhadapan dengan integral tak tentu.

\section{Hasil dan Pembahasan Hasil Penelitian}

Dari 5 buah soal yang diberikan didapat jawaban mahasiswa sebagai berikut

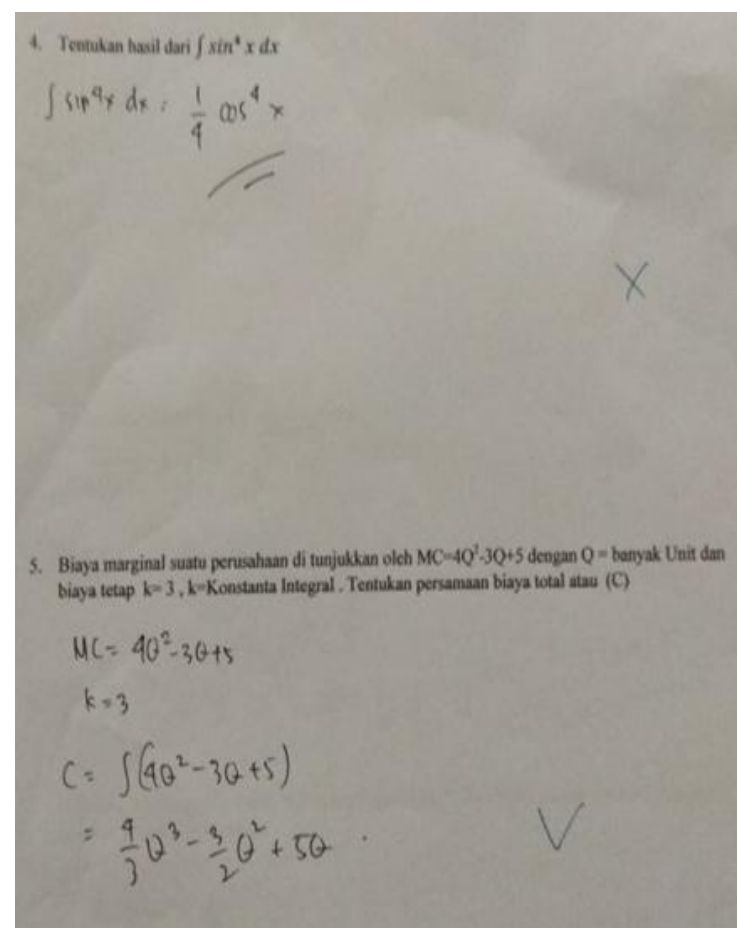

Kairuddin.. Analisis Kesalahan Mahasiswa Baru dalam Mengerjakan Soal-Soal Kalkulus Integral Tak Tentu. Jurnal Inspiratif, Vol 3. No. 3 Desember 2017 
Mahasiswa A ini tidak mampumpu mengerjakan soal dengan benar, bahkan ada soal yang sama sekali tidak dikerjakan sehingga skornya adalah 0 . Kesalahan yang dilakukan mahasiswa ini adalah dia kurang memahami maksud soal, sehingga mahasiswa ini kurang serius dalam mengerjakan soal

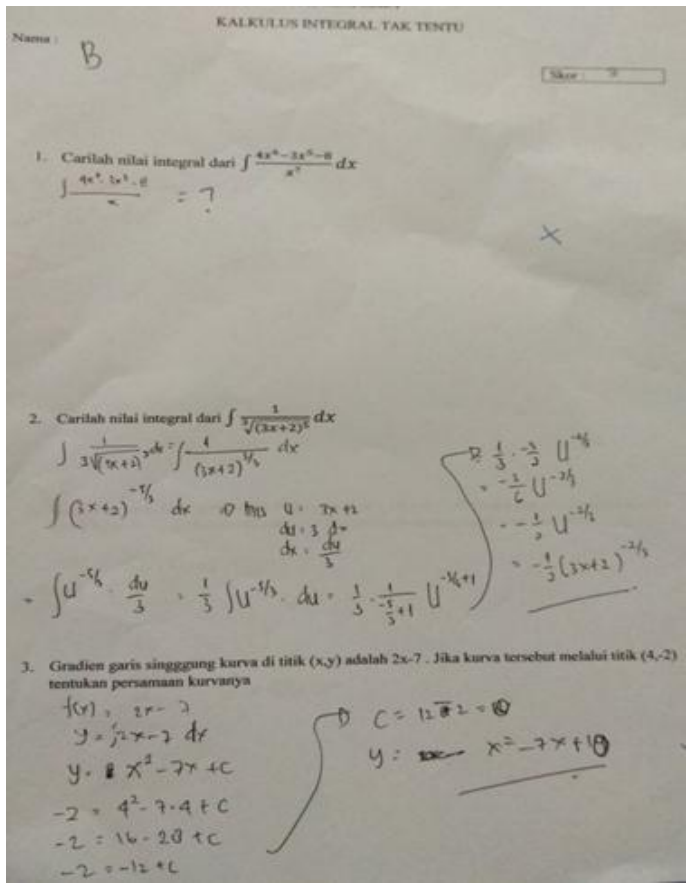

yang di berikan. Uuntuk soal nomor 3 disini mahasiswa A menunjukkan jalan penyelesaian yang hamper benarn naun pada tahap akhir penyelesaian soal, responden kurang teliti dalam menghitung hasil akhir soal sehingga di dapatkan hasil yang tidak sesuai dengan jawaban yang benar.

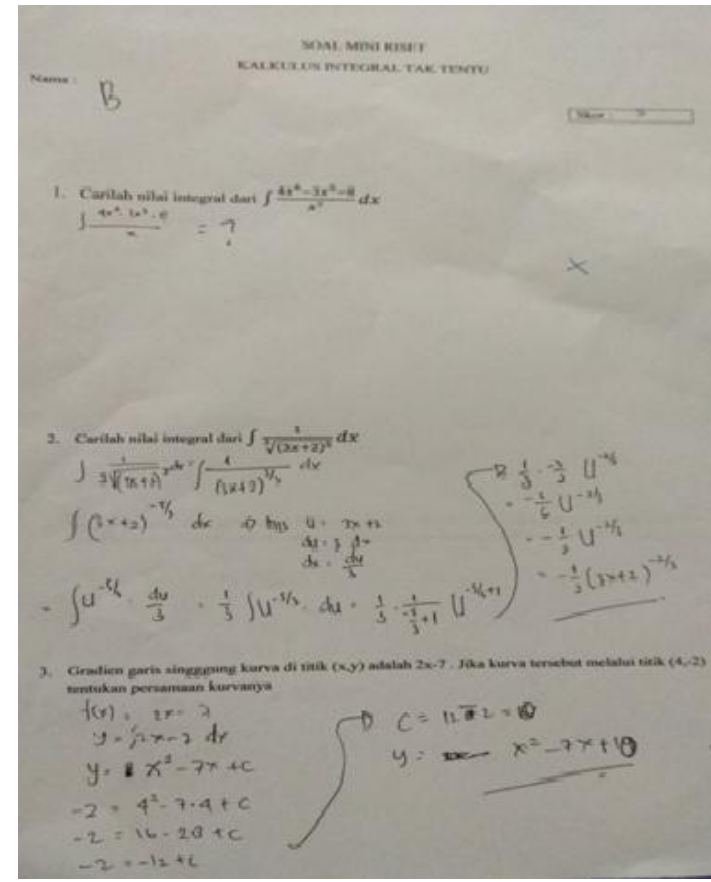

Gambar 2. Jawaban mahasiswa B

Responden mampu mengerjakan 3 soal dengan benar dari 5 soal yang diberikan. Responden dalam hal pengerjaan soal sudah menampakkan pamahaman akan soal yang di kerjakannya terlihat dari jumlah soal yang dia kerjakan dan jawaban yang di buat. Langkah langkah penyelesaian soal dari responden ini sudah terperinci dan sesuai dengan jawaban akhirnya. Untuk jawaban yang salah mungkin di akibatkan kurang mendalami konsep integral tak tentu. 

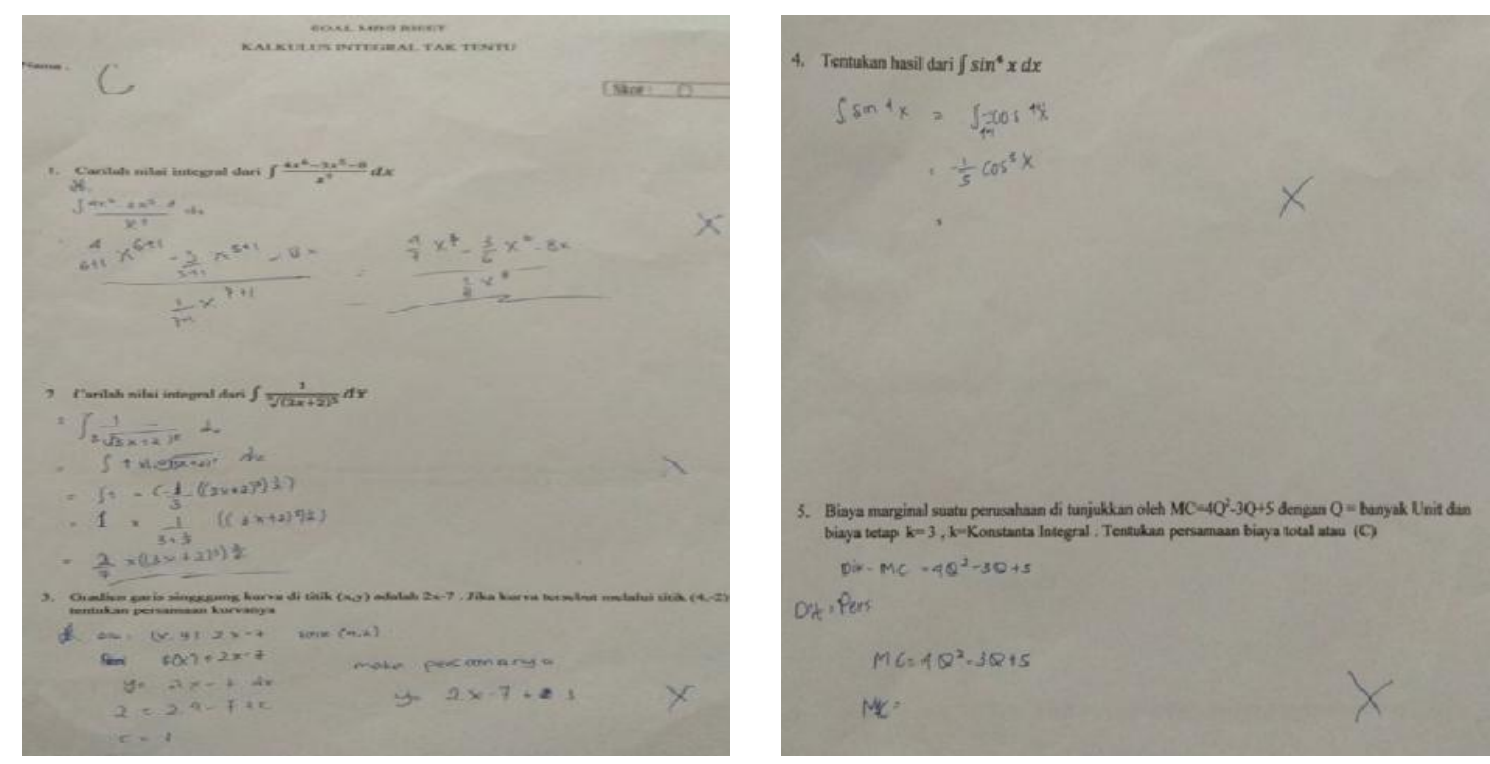

Gambar 3. Jawaban mahasiswa C

Cara penyelsaian soal yang di berikan responden ini sebenarnya sudah mendekati dengan konsep yang sesungguhnya terlihat di mana responden mengisi semua jawaban yang di berikan, namun penyelesian dari soal tersebut tidak sesuai dengan yang di harapkan, terlihat dari beberapa soal

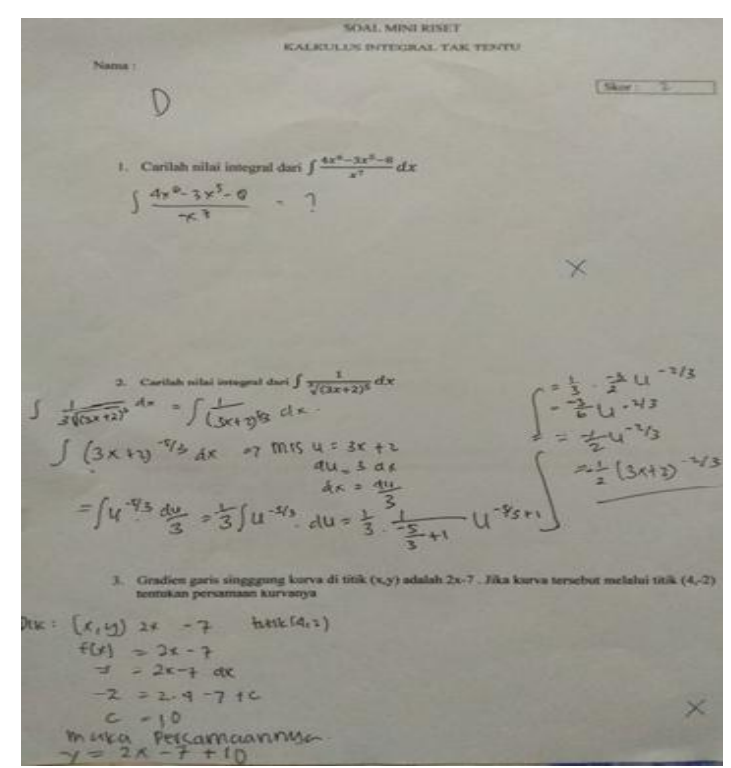

yang mengalami kebuntuan di tengah tengah penelesaiannya sehingga hasil akhirnya pun salah. Dalam hal ini responden tidak memahami konsep penyelesain soal integral. Sehingga dari 5 soal yang diberikan tidak satupun didapat jawaban akhir yang benar.

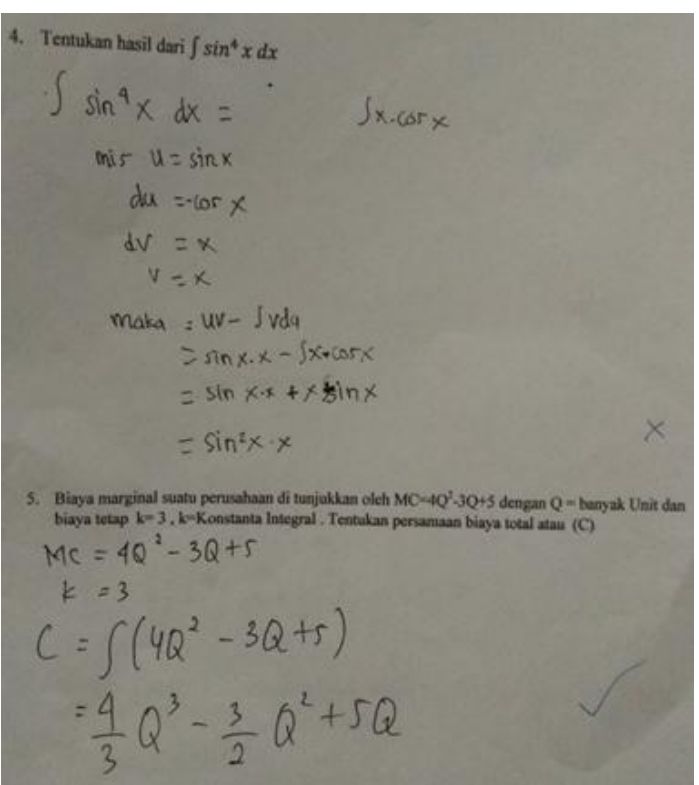

Gambar 4. Jawaban mahasiswa D

Mahasiswa D ini hanya mampu mendapatkan hasil akhir yang benar 2 soal dari 5 soal yang diberikan. Untuk responden ini terlihat sudah sedikit memahami konsep, terlihat dari soal kategori mudah dan sedang dapat di

Kairuddin.. Analisis Kesalahan Mahasiswa Baru dalam Mengerjakan Soal-Soal Kalkulus Integral Tak Tentu. Jurnal Inspiratif, Vol 3. No. 3 Desember 2017 
kerjakan dengan benar, namun untuk soal yang lainnya responden kurang

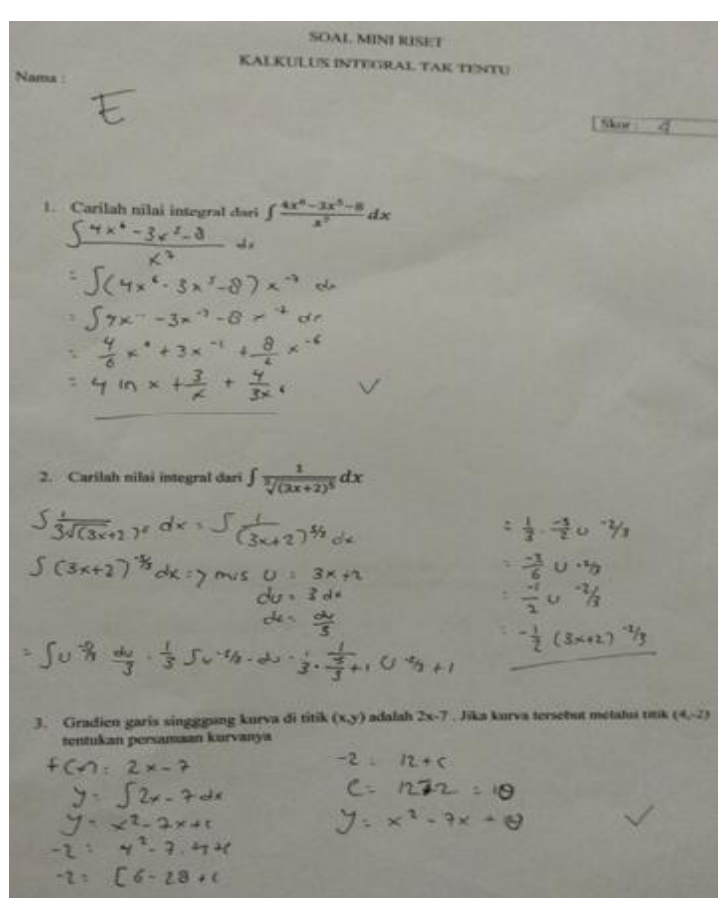

teliti dalam mengerjakan soal.

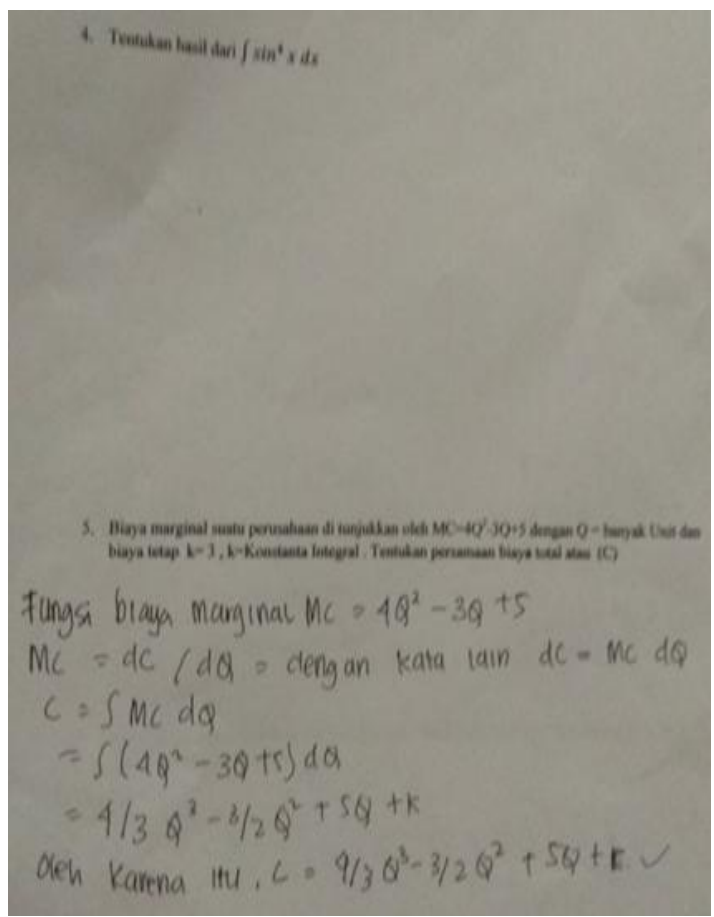

Gambar 5. Jawaban mahasiswa E

Mahasiswa E ini sudah mampu mendapatkan hasil akhir 4 soal yang benar dari 5 soal yang diberikan. Responden ini sudah memahami konsep dengan baik dan benar, terlihat dari caranya menyelesaikan soal respon ini memberikan langkah langkah penyelesaian secara terperinci dan hasil akhir yang benar.Kesalahan pada responden ini yaitu tidak mengisi jawaban untuk integral trigonometri hal ini mungkin di sebabkan oleh kurangnya pemahaman responden mengenai materi ini.

\section{Pembahasan}

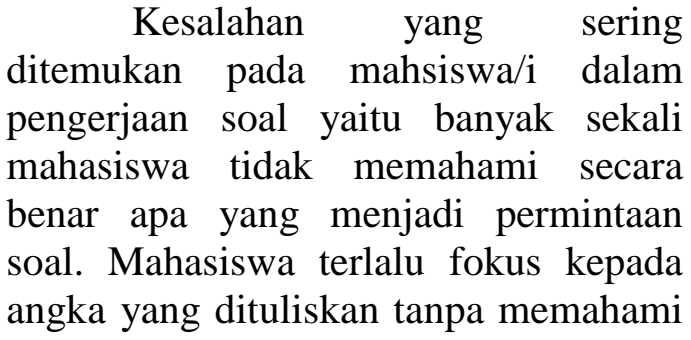

apa yang menjadi tujuan dari soal tersebut. Kurangnya ketelitian dalam mengerjakan soal sering sekali menjadi awal sesuatu membuat kesalahan padahal mahasiswa/i sudah memahami secara benar apa yang menjadi permintaan soal. Kesalahan ini sering terjadi saat menjumlahkan angka-angka dan penulisan angka pada sebagian penjumlahan sehingga pada hasil akhirnya sering ditemukan kesalahan. Mahasiswa/i sering terfokus kepada rumus yang ada tanpa mereka memahami konsep dan teori dasar dari integral tentu padahal dalam mempelajari sebuah materi yang diperlukan adalah proses pemahaman terhadap konsep. Masalah yang muncul dari data yang didapat teknik pengitegrasian sederhana yang masih ditemukan kesalahan padahal materi dari integral bukanlah materi yang masih baru bagi para mahasiswa/i namun masih ada ditemukan kesalahan.

Kairuddin.. Analisis Kesalahan Mahasiswa Baru dalam Mengerjakan Soal-Soal Kalkulus Integral Tak Tentu. Jurnal Inspiratif, Vol 3. No. 3 Desember 2017 
Mahasiswa masih sering kurang teliti dalam mengintegralkan sehingga ketika memasukkan nilai variabel pada fungsi pada hasil akhirnya mengalami kesalahan

Pada proses wawancara yang dilakukan setelah dilakukan serangkaian test/kuis kepada mahasiswa/i ada beberapa tanggapan yang muncul dari para mahasiswa/i

- Mahasiswa A berpendapat bahwa soal yang diberikan cukup sulit karena dalam integral tak tentu dia tidak paham

- Mahasiswa B berpendapat bahwa soal yang diberikan tidak terlalu sulit karena menurut dia integral tak tentu masih cukup mudah untuk dipahami dan juga soal yang disajikan juga masih sederhana

- Mahasiswa C berpendapat bahwa soal yang diberikan cukup sulit namun integral tak tentu merupakan materi yang masih lebih mudah dibandingkan jenis integral yang lain

- Mahasiswa D berpendapat bahwa soal yang diberikan tidak terlalu sulit karen asoal yang diberikan masih sederhana bagi kalangan mahasiswa dan materi integral tak tentu merupakan materi yang masih lebih mudah dipahami dibandingkan yang lainnya

- Mahasiswa E berpendapat bahwa soal yang diberikan cukup mudah dan juga materi ini memang cukup sederhana namun untuk integral trigonometri cukup menyulitkan mahasiswa.

Sejalan dengan pendapat Surya, dkk. (2013) "Pertanyaan-pertanyaan yang diberikan diharapkan dapat mendukung pencapaian tujuan pembelajaran. Hal ini diperlukan untuk menyampaikan pertanyaan-pertanyaan tantangan atau semacam pertanyaan kognitif yang berlainan atau bertentangan dalam suatu kondisi untuk mengharapkan para siswa untuk memvisualisasi pemikiran dan berpikir kritis, kreatif dalam matematika penyelesaian masalah.

Dari beberapa orang yang dijadikan sampel setelah diwawancarai dengan pertanyaan yang diajukan peneliti banyak mahasiswa berpendapat bahwa soal yang diberikan merupakan soal yang masih cukup sederhana untuk dunia perkuliahan namun setelah dilakukan pemeriksaan terhadap jawaban soal ternyata masih banyak ditemukan kesalahan hal ini tidak dipungkiri bahwa banyak mahasiswa/i ynag kurang teliti dalam menjawab pertanyaan. Jawaban pertanyaan soal tidak tepat dan juga kurang memahami maksud dan tujuan soal. Namun tidak banyak juga mahasiswa yang berpendapat bahwa soal cukup sulit karena mahasiswa/i yang dijadikan sampel adalah beberapa diantara mahasiswa yang kurang mencintai dunia kalkulus.

\section{Kesimpulan}

Pada kenyataan yang ditemukan dalam dunia mahasiswa tentang pemahaman integral tak tentu adalah hal yang masih bisa ditolerir . Kenyataan yang muncul di lapangan bukan mahasiswa tidak memahami konsep dasar dari integral tak tentu namun masalah yang muncul mahasiswa/i sering kurang teliti dalam pengoperasian angka-angka dan juga mahasiswa kurang memahami maksud dari permintaan soal. Dalam pengerjaan soal integral tak tentu mahasiswa sering terfokus dengan pengoperasian angkaangka tanpa memperhatikan apa yang menjadi permintaan soal. Dalam pengerjaan soal test/kuis mahasiswa 
secara keseluruhan mampu menjawabnya namun banyak sekali mahasiswa sering keliru dengan pengoperasian angka-angka dan juga pengintegrasian yang salah sehingga ketika dimasukkan nikai fungsinya menghasilkan jawaban yang salah.

Selain memberikan serangkaian test/kuis juga dilakukan proses wawancara terhadap sampel dari beberapa sampel ada yang berpendapat bahwa soal yang disajikan dikategorikan sebagai soal yang masihh cukup sederhana dalam dunia perkuliahan dan juga materi integral merupakan jenis integral tak tentu yang masih cukup mudah dipahami namun dari beberapa sampel yang diambil ada beberapa orang yang berpendapat bahwa soal yang disajikan dikategorikan kedalam soal yang cukup sulit dan hal itu bisa dilihat dari pengerjaannya terhadap soal. Mahasiswa/i yang berpendapat bahwa soal yang disajikan masih cukup sederhana bukan tidak sering memiliki persentase kesalahn yang tinggi karena dari proses pemeriksaan soal yang dilakukan persentase kesalahannya cukup tinggi. Hal ini disebabkan kurang ketelitian dalam pengoperasian angkaangka dan pengintegralan yang juga kurang teliti.

\section{DAFTAR PUSTAKA}

Abdurrahman. M. 2010. Pendidikan Bagi Anak Berkesulitan Belajar. Jakarta: Rineka Cipta.

Athira, A. M., Bennu, S., \& Rizal, M. (2015). Analisis kemampuan siswa SMP di Kota Palu dalam memecahkan masalah segiempat berdasarkan gaya kognitif. Jurnal Sains dan
Teknologi Tadulako, IV(1), 7279. Basir

Hikmawati, Kamid, \& Syamsurizal. (2013). Pengaruh penggunaan media pembelajaran dan gaya kognitif terhadap hasil belajar matematika siswa kelas viii madrasah tsanawiyah. TeknoPedagogi, III(2), 1-11.

Leithold, L. 1993. Kalkulus dan Ilmu Ukur Analitik Jilid 2 (Alih Bahasa oleh S. M. Nababan). Jakarta: Erlangga.

Nurafni. (2016). Gaya kognitif field independent mahasiswa terhadap pemahaman konsep limit. Dalam Prosiding Seminar Nasional Matematika dan Pendidikan Matematika (SENATIK) I diselenggarakan pada 13 Agustus 2016 (h.230239). Semarang: Prodi. Pend. Matematika FPMIPATI Universitas PGRI Semarang

Rahmania, L., \& Rahmawati, A. (2016). Analisis kesalahan siswa dalam menyelesaikan soal cerita persamaan linier satu variabel. Jurnal Matematika dan Pendidikan Matematika, I(2), 165-174.

Surya, E., Sabandar, J. Kusumah, Y.S., Darhim. (2013). Improving of Junior High School Visual Thinking Representation Ability in Mathematical Problem Solving by CTL. IndoMS. J.M.E, Vol. 4 No. 1, pp. 113-126.

Kairuddin.. Analisis Kesalahan Mahasiswa Baru dalam Mengerjakan Soal-Soal Kalkulus Integral Tak Tentu. Jurnal Inspiratif, Vol 3. No. 3 Desember 2017 